Elsevier Editorial System(tm) for Biochimie

Manuscript Draft

Manuscript Number: BIOCHI-D-05-00188R2

Title: RNAi in mice: a promising approach to decipher gene functions in vivo

Article Type: Review Article

Section/Category:

Keywords: RNAi, mice, knockdown, Cre-loxP, Fgfr2

Corresponding Author: Dr Xavier COUMOUL, PhD

Corresponding Author's Institution:

First Author: Xavier COUMOUL, PhD

Order of Authors: Xavier COUMOUL, PhD; Chu-Xia DENG, PhD

Manuscript Region of Origin:

Abstract: RNA interference (RNAi) is a simple and powerful tool widely used to study gene functions in many species. Vector-based systems using RNA polymerase III promoters have been developed to achieve stable expression of small interfering RNA (siRNA) or small hairpin RNA (shRNA) in mammalian cells.

Recent investigations demonstrated that when, combined with the Cre-loxP system, the vector based RNAi can be used to achieve conditional or tissue specific knockdown of endogenous genes with high efficiency in mice. Here, we review these recent progresses and discuss the advantages, limitations and future development of this emerging technology. 
Ms. Ref. No.: BIOCHI-D-05-00188

Title: RNAi in mice: a promising approach to decipher gene functions in vivo

Biochimie

Dear Dr. Monier,

We are pleased to submit our revised manuscript (BIOCHI-D-05-00188) "RNAi in mice: a promising approach to decipher gene functions in vivo" to Biochimie for publication.

We thank the reviewers for their valuable comments and have revised the manuscript accordingly (all the changes are marked with bold face). We hope that the revised manuscript will be suitable for publication in Biochimie.

Responses to Reviewer \#1,

- The minor point has been corrected (showing)

Responses to the Editorial Board

- Figures are now provided in tiff files.

Best regards,

Xavier COUMOUL, $\mathrm{PhD}$

INSERM U490, Université PARIS 5

45 rue des Saints-Pères

75270 Paris Cedex 06

Tel : 0033(+1)42863359 Fax : 0033(+1)42862075

E-Mail : xavier.coumoul@univ-paris5.fr 
RNA interference (RNAi) is a simple and powerful tool widely used to study gene functions in many species. Vector-based systems using RNA polymerase III promoters have been developed to achieve stable expression of small interfering RNA (siRNA) or small hairpin RNA (shRNA) in mammalian cells. Recent investigations demonstrated that when, combined with the Cre-loxP system, the vector based RNAi can be used to achieve conditional or tissue specific knockdown of endogenous genes with high efficiency in mice. Here, we review these recent progresses and discuss the advantages, limitations and future development of this emerging technology. 


\section{RNAi in mice: a promising approach to decipher gene}

\section{functions in vivo}

Xavier Coumoul $^{1^{*}}$ and Chu-Xia Deng ${ }^{2^{*}}$

${ }^{1}$ INSERM UMR-S 490, Unite de Toxicologie Moléculaire, 45 rue des Saints-Pères, 75270 Paris Cedex 06, FRANCE

Tel: $(33+1) 42863359$; Fax: $(33+1) 42862072$

E-mail: xavier.coumoul@univ-paris5.fr

${ }^{2}$ Genetics of Development and Disease Branch, 10/9N105, National Institute of Diabetes, Digestive and Kidney Diseases, National Institutes of Health, Bethesda, Maryland, MD 20892, USA

Tel: (301 ) 402-7225; Fax: (301) 480-1135

Email: chuxiad@bdg10.niddk.nih.gov

* To whom the correspondence should be addressed 


\begin{abstract}
RNA interference (RNAi) is a simple and powerful tool widely used to study gene functions in many species. Vector-based systems using RNA polymerase III promoters have been developed to achieve stable expression of small interfering RNA (siRNA) or small hairpin RNA (shRNA) in mammalian cells. Recent investigations demonstrated that when, combined with the Cre-loxP system, the vector based RNAi can be used to achieve conditional or tissue specific knockdown of endogenous genes with high efficiency in mice. Here, we review these recent progresses and discuss the advantages, limitations and future development of this emerging technology.
\end{abstract}

Keywords: RNAi, mice, knockdown, Cre-loxP, Fgfr2 


\section{Introduction}

Since the publication of the first transgenic mice in 1980 [1], mouse genetics constitutes one of the primary fields to explore the consequence of manipulating gene expression. The transgenic approach and gene targeting (knockout) in mice make possible to modify any genes with various mutations, i.e. over expression, constitutive activation, loss of function, hypomorphic mutation, conditional and/or tissue specific inactivation [2-5]. Despite great efforts have been made to improve efficiency of these techniques, the manipulation of genes remains difficult and time-consuming. For example, the generation of a knockout or conditional knockout mouse requires years of work and sometimes does not yield to significant results. This accounts for one of the main reasons why the published knockouts represent only $10 \%$ of mouse genes of 30,000 [6]. On the other hand, generation of transgenic mice remains the quickest way to obtain results on the function of a specific gene, although it primarily gives information from overexpression. Recently, many laboratories have developed various methods to knockdown gene expression using RNAi in mice. In this review, we will mainly discuss these recent progresses. Readers who are interesting in any other aspects of RNAi are referred to a number of other recent reviews [7-10]. 


\section{How RNAi works?}

RNA interference corresponds to a specific target mRNA degradation involving small perfectly homologous double-strand RNAs also called small interfering RNAs (siRNAs). This leads to a decrease (but not absence) of expression of the corresponding protein. This natural process has been discovered in 1998 in the invertebrate nematode Caenorhabditis elegans $[11,12]$. Other studies have shown that RNAi is a common process encountered in unicellular protozoa's, insects, fungi, but also plants and vertebrates [13]. Originally, RNAi has probably evolved to fight against viruses and transposable elements that include a double strand RNA step in their replication cycle [14]. It is also generally assumed that RNAi is involved in developmental processes in multicellular organisms and chromatin structure regulation $[15,16]$.

Basically, when a double strand RNA or an RNA containing an equivalent structure (generally due to homologous folding) is introduced or produced in a cell, a ribonuclease called Dicer recognizes this molecule and processes it into short double strand RNA of 21-base pairs (bp) containing 2-nucleotide 3'-overhangs. These molecules, called siRNAs, can also be easily introduced in any cells during transient transfection experiments. A multi-subunit complex called RISC (RNA-induced silencing complex) then binds one molecule of siRNAs (Fig. 1). Among its subunits, a helicase unwinds the siRNA and one of the strands is used as bait by a homology-searching component to catch an endogenous target mRNA bearing the same sequence. Upon binding, the mRNA is degraded by the RISC endonuclease and exonuclease subunits; a new cycle then begins. Thus, any mRNA bearing a homologous sequence with a siRNA is degraded and its expression is knocked down to $10-40 \%$ of its normal levels [17]. 
In addition to this linear mechanism, plants, worms and insects have developed an amplification loop with an additional enzyme complex called RdRp for RNA-dependent RNA polymerase [18]. The siRNA provides sequence-specific primers and the target mRNA is used as the template. The RdRp complex produces large quantities of siRNAs and then an additional defense mechanism. This alternate step does not exist in mammals [19-21].

RNA interference techniques have become widely used in numerous laboratories since Elbashir and al [22-24] first described efficient knockdown in transfected mammalian cells with in vitro synthesized siRNAs. Their size needs to be $<22$ base pairs. Longer siRNAs activate an interferon reaction, leading to a general inhibition of translation, rather than the desired specific knockdown [22-24]. However, an increasing number of publications using microarrays suggest that short siRNAs $(<22$ bp) might also induce non-specific knockdown [25-27]. On the other hand, a few studies demonstrated a very specific effect of one siRNA on a large scale [28-30]. One evoked reason for an eventual non-specific effect is a special interferon response for short siRNA $[25,27]$. Another reason might be the huge quantity of small dsRNA that are transfected in each single cell. The development of sh (small hairpin) RNA-synthesizing vectors has allowed a better control of in vitro RNA interference. Indeed, several laboratories have developed new plasmids containing polymerase III promoters, like the ones of the U6 and $\mathrm{H} 1$ genes, known to synthesize small RNA. Tho se vectors allow synthesis of $50 \mathrm{bp}-$ long single strand RNA that folded in 21-23 bp dsRNA with a small hairpin in the middle. These shRNAs lack a 5' cap and a long polyadenylated tail [31-33]. 
Alternatively, other vectors have been created that allow synthesis of two complementary short RNA duplexes forming then a siRNA [34, 35].

These constructs have several advantages. First, they allow a smoother synthesis of shRNAs in the cell compared to the brutal transfection of numerous siRNA molecules. Secondly, the time of action of a shRNA lasts much longer than a siRNA does, as the shRNA vectors can be stably integrated into the genome of recipient cells [36]. Finally, expression of these vectors can be controlled by inducible elements to achieve temporal and spatial knockdown of genes of interest, which will be discussed further in this review.

\section{RNAi in mice}

RNA interference can be performed at the whole animal level. C. elegans and Dro sophila can be easily manipulated by soaking the animals in a solution containing siRNAs or by adding bacteria expressing siRNAs to the diet [37, 38]. Significant and quick knockdown (72 hours after soaking) can be obtained with these procedures; however, they cannot be applied for mammals.

RNAi mediated gene knockdown in mice has been performed throughout various techniques at multiple levels. siRNAs or long dsRNAs (>500 bp) synthesized by an oocyte-specific promoter (from a vector) have been injected into mouse oocytes and zygotes to study gene functions during embryonic development [21, 39]. The injected oocytes or embryos can be maintained in culture condition in a specific medium and their phenotypes and growth properties can be monitored. These studies showed that efficient knockdown of transgenic eGFP, endogenous c-Mos or ECadherin could be achieved. We have mentioned earlier that long dsRNA might 
generated a non-specific response due to their length; however, it appears that, in oocytes, they do not activate the same pathways previously described in somatic cells. Thus, this technique looks suitable to study early development of the embryos.

Taken advantage of the dominant nature of the RNAi, embryonic ste m (ES) cells carrying stably integrated shRNAi vectors were also used to generate embryos by tetraploid aggregation method $[40,41]$. Because the tetraploid embryos can only form the placenta and the yolk sac in the fusion embryos owing to their increased ploidy, the entire embryo proper is ES cells derived. In one of the study, the a uthors showed that strong expression of an shRNA targeting RasGAP, a p120-RAS GTPaseactivating protein, impaired normal development at embryonic day 9.5. Severity of the phenotype was concordant with the levels of shRNA knockdown [40]. The delivery has also been improved by the use of various adeno-, lenti- or retrovirus to increase transfection efficiency $[42,43]$. All those experiments have shown efficient knockdown of exogenous or endogenous genes like p53, Bim, CD25 or CD8 $\alpha$. Additionally, Hemann and co-workers introduced hematopoietic stem cells expressing p53-targeting shRNA into irradiated mice and observed several kinds of phenotypes in reconstituted organs, which were correlated with the shRNA expression levels [44]. All those experiments show that RNAi could be performed in mice at the cellular or embryonic level.

To target an adult mice, shRNAs or siRNAs has been administrated using a method called "tail vein injection" (or "hydrodynamic transfection method"), which had been widely used before to allow expression of a variety of plasmids in the liver [45-47]. Basically, a solution of DNA (ranging from 10-500 $\mu$ g desolved in $2.5 \mathrm{~mL}$ of Ringer's 
solutions) is injected into recipient mice through tail vein with a 27 -gauge needle. The levels of transgene expression depend on the volume and injection rate. Under slow conditions of injection, the DNA enters the blood stream and is rapidly degraded by the blood nucleases. The "high-pressure" delivery leads to the accumulation of the DNA solution in the inferior vena cava; indeed the injected volume is almost equal to the blood volume and the cardiac output is overflown by the rapid delivery of the DNA solution. The resulting high pressure surrounding the liver allows the "DNA transfection" into the parenchyma. Toxicity studies show that most animals recover well from the procedure [45]. Expression of a gene coding by the DNA can be observed within the first 24 hours and approximately $50 \%$ of hepatocytes express the transgene [45, 47]. In addition, several laboratories have shown that it was also possible to deliver naked plasmid DNA to various tissues (i.e. muscle and liver) through direct injection into the tissue or into the vessels surrounding the organ (portal vein, hepatic vein or bile duct for the liver) [47].

Lewis et al (2002) were the first to knockdown transgenic eGFP expression using RNAi in mice using the hydrodynamic transfection method [48]. Human viral RNAs (Hepatitis B and C) have also been targeted by other laboratories using the same procedure [49-51]. More recently, Song and colleagues performed a similar experiment on the Fas gene, a protein sometimes involved in autoimmune hepatic diseases, and protected the mice against fulminant hepatitis [52]. Those experiments have shown that the liver could be easily targeted to disrupt functions of exogenous, or endogenous genes. Unfortunately, this could be obtained mainly in the liver and only for a short period of time (around 1 week). Repeated injections must be performed to reach an efficient 
knockdown effect [48]. The use of cationic liposome has shown that it was possible to target other organs in addition to the liver with a GFP-based RNAi experiment [53]. The protocol is closed to the ones used commonly for transient transfection experiments at the cell culture level: a cationic lipid is complexed with siRNA and plasmid DNA coding the target mRNA. Equivalent knockdown of eGFP expression in the liver and the spleen was observed $72 \mathrm{~h}$ after intravenous administration of the siRNA specific to eGFP. In the same study, the authors also demonstrated that the intraperitoneal injected siRNA specific for TNF $\alpha$ favored development of sepsis in liposaccharide-trea ted mice [53].

Most notably, Hasuwa and colleagues (2002) used a transgenic approach by directly injecting an shRNA construct against eGFP to the pronucleus of zygotes [54]. The transgenic mice were then crossed with mice that ubiquitously express the eGFP gene. Their data demonstrated that expression of the eGFP siRNA efficiently silenced the eGFP gene in every part of the mouse analyzed. This study proves in principle that shRNA can knockdown genes in mice.

\section{Inducible RNAi in mice}

Our review of literature thus far has revealed the feasibility of RNAi-mediated gene knockdown in mice with high efficiency. However, with a threat of knockdown-induced lethality, new strategies have taken in account the possibility to generate inducible or tissue restricted models. These models in theory can bypass embryonic lethality and allow the study of specific genes in specific tissues. Several approaches have been developed in cultured cells, including tetracycline-inducible shRNA, ecdysone- 
responsive system, and tamoxifen-induced Cre/loxP recombination system $[30,32,55-$ $59]$.

Although all these approaches are promising, so far only Cre/loxP mediated RNAi has been reported to knockdown endogenous genes in mice. Two studies used lentivirus based RNAi systems, in which shRNA expression is controlled by a lox-stop-lox element. Because the stopper is placed between the TATA-box and the transcription start site of the U6 promoter, the shRNA cannot be expressed until it (lox-stop-lox element) is deleted by Cre-mediated excision [60, 61]. The third study by our group used a plasmid-based strategy $[32,33]$. Our data demonstrated that the plasmid-based RNAi system is both simple and easy to use, and works with high efficiency in silencing expression of endogenous genes.

In this approach, a neomycin cassette was inserted in the U6 RNA polymerase III promoter to disrupt its activity. The neo gene not only functions as a stopper but also serves as a selection marker when the shRNA construct is used in cell culture system. The neomycin cassette is flanked by loxP sites and can be deleted through the Cre/loxP mediated recombination [5]. After checking the efficiency of the system at the tissue culture level on two endogenous genes, Fgfr2 and Survivin, we found that the U6 activity can be completely restored upon the excision of the neo by Cre/loxP mediated recombination [32]. We then decided to generate mice bearing our Fgfr2-targeting construct (U6-ploxPneo-Fgfr2) to test its in vivo efficiency. FGFR2 is one of the four high affinity FGF receptors that mediate the signaling of, at least, 22 FGF ligands [62]. In humans, missense mutations of FGFR2 have been related to craniosynostosis and limb abnormalities [62]. Fgfr2 also plays an important role in embryonic development and 
organogenesis [62]. Consistent with our in vitro study showing that the presence of the neo inhibits the U6 promoter activity, transgenic mice bearing the U6-ploxPneo-Fgfr2 shRNA construct showed no abnormalities. When crossed with EIIa-Cre transgenic mice, which express Cre in the mouse germline [63], ploxPneo is excised leading to activation of the U6 promoter and FGFR2-shRNA synthesis (Fig. 2A,B). We next determined levels of Fgfr2 expression by RT-PCR and found that all U6-Fgfr2;EIIa-Cre embryos exhibited dramatically reduced Fgfr2 transcripts while no obvious alteration was observed in all control embryos (Fig. 2C). Our analysis also revealed that $U 6-F g f r 2$ RNAi-mediated suppression is specific to $F g f r 2$ but not to any other family members (Fig. 2C). Next, we performed realtime-PCR analysis and were able to confirm dramatic downregulation of Fgfr2 transcripts in the U6-Fgfr2;EIIa-Cre, but not in any other control embryos (Fig. 3B).

Previous studies showed that Fgfr2 mutant embryos generated by gene targeting died during embryonic stages [64-66]. Consistently, we found that a majority of U6Fgfr2;EIIa-Cre embryos died at middle gestation (Fig. 3A). On the other hand, when crossed with a transgenic strain that expresses Cre in the progress zone of the limb [67], embryos reach birth but with associated limbs and digits abnormalities (Fig. 3B), demonstrating in principle that the combination of the Cre/loxP and RNAi approaches can be used to decipher gene function in a tissue specific manner.

\section{Advantages, limitations, and perspectives}

Most RNAi experiments performed in mice have been compared with counterpart recombination knockout studies and most of them have revealed similar phenotypes [21, 33, 39, 40, 60, 61]. However, RNAi knockdown in mice may have several advantages. 
Currently, knockouts studies represent only $10 \%$ of total mouse genes [6]. Generation of transgenic mice carrying RNAi construct is fast; in our hands, we were able to produce several pure carriers in only 3 months (the time schedule to produce regular transgenic mice) compared to 12-24 months for conditional gene knockouts. Moreover, because RNAi acts dominantly, only one allele of transgene is needed to suppress the endogenous target gene, it reduces the time needed for breeding together two mutant alleles required by conditional knockout of genes with recessive nature. This advantage becomes more obvious when genetic interaction of two or more genes is studied [64, 68]. Thus, compared with the gene targeting technique, RNAi approach is both fast and simple, and therefore should be widely accessible. In this aspect, the existence of a large collection of Cre transgenic lines (hhttp://www.mshri.on.ca/nagy/cre-pub.html) should make it possible to have a quick assessment of RNAi-mediated gene knockdown in the tissue specific fashion.

On the other hand, RNAi-mediated gene knockdown cannot replace gene targeting because expression of endogenous genes is not completely repressed. Instead, it should be used as a complement approach to study functions of genes, especially to those whose absence results in embryonic or early postnatal lethality. Generation of mice carrying mild phenotypes or various hypomorphic alleles could greatly facilitate studies in many fields of biological sciences. For example, knockout DNMT1 is lethal but only $10 \%$ expression is enough for a mouse to survive. On the other hand, those mice have a clear phenotype, given information on the gene function [69]. Such level of downregulation is clearly in the range of an RNAi experiment. 
Those advantages must not hide the limits of this new technique: among them, insertion of transgenes is still a matter of random in the genome. Then, the RNAi construct will always be dependant of the so-called positional variegation [70]. It was recently reported that the position effect could be minimized or overcome using an insulator [71]. Alternatively, RNAi construct can be targeted in the ES cells to a site that allow ubiquitous expression of the exogenous genes, such as Rosa-26 locus [72]. In addition, non-specific knockdown might be the biggest challenge for RNAi in vivo experiments. This problem might be solved by a careful selection of the RNAi sequences. Target structure, base composition and internal thermodynamic stability are important parameters to design a siRNA. The design of the siRNA or shRNA remains crucial and carefully accomplished [73]. Useful web sites for the design of effective si/shRNAs can be found in a recent review [74]. Using different shRNA or siRNA targeting the same gene has also been suggested to overcome this problem [44]. Finally, creating a transge nic line, although faster than the knockout strategy, is still time consuming. It is still appropriate to first assess the efficiency of the construct or the siRNA in transient transfection experiment in cell culture. New approaches for mammalian systems might have also been developed that used type II promoten and RNA polymerase II; two recent papers mentioned such techniques that appear to be more effective than the now traditional shRNA option and that could also be tightly regulated $[75,76]$.

Because shRNA constructs can be injected into the pronucleus of fertilized eggs, it can be applied to many other species where ES cells have not been established. A successful example has been reported in rat [54]. With the continuous increased 
efficiency RNA interference and improved delivery in vivo, it is conceivable to imagine new human therapeutics involving controllable RNAi constructs to knockdown expression of alleles carrying missence mutations commonly seen in numerous forms of genetic diseases, such as those occurred in FGF receptors $[62,77]$.

\section{Acknowledgments}

This work was supported by the intramural support of NIDDK, NIH to Chu-Xia Deng, and INSERM U490, Université Paris 5 to Xavier Coumoul. 


\section{Figure legends}

Figure 1. An overview of RNA interference. See text for explanations.

Figure 2. Cre mediated deletion of the neo from U6-ploxPneo-Fgfr2 transgene knockdown Fgfr2 transcripts. (A) Structure of U6-ploxPneo-Fgfr2 transgene prior to and after deletion of ploxPneo. (B) Northern blot analysis showing that U6-Fgfr2 transgene is only expressed in U6-Fgfr2;EIIa-Cre embryos, as evidenced by the presence of 86 nucleotides transcription product. Equal RNA loading was assessed by ethidium bromide staining of the upper portion of the gel (lower). (C) RT-PCR analysis of Fgfrl-4 expression in embryos of different genotypes. Wt: Wild type; U6: U6-ploxPneo-Fgfr2; Cre: EIIa-Cre; and U6;Cre: U6-Fgfr2;EIIa-Cre. The first row is a longer exposure of the second row. All samples are from E12.5 embryos.

Figure 3. Phenotypes associated with Fgfr2 knockdown mediated by RNAi. (A) E11.5 U6-Fgfr2;EIIa-Cre and wild type embryos, showing that knockdown of Fgfr2 from germline results in embryonic lethality. (B) P19 U6-Fgfr2;AP2-Cre and wild type mice. showing abnormal limbs (arrow) in the mutant mice.

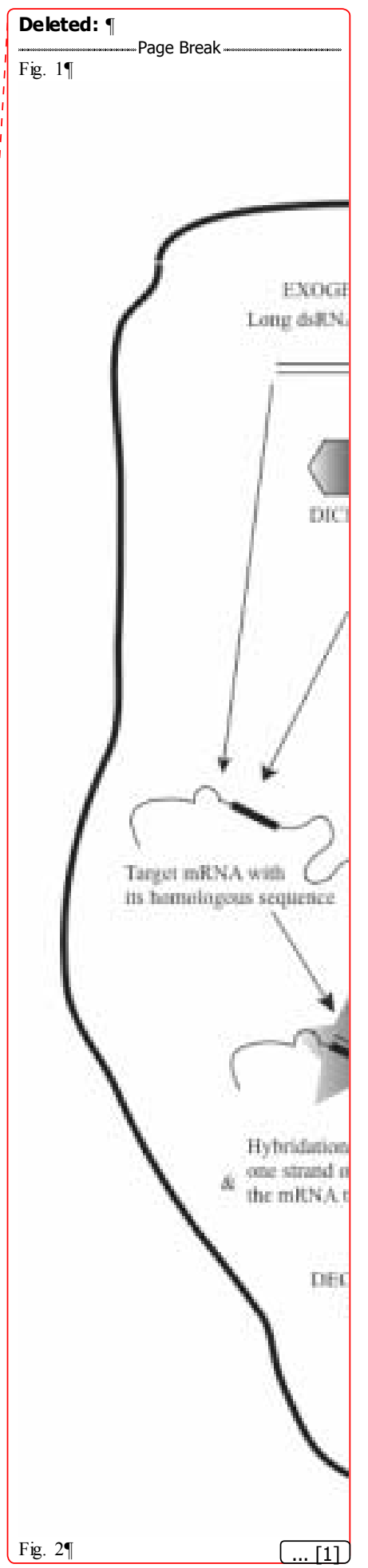




\section{References}

[1] Gordon, J.W., Scangos, G.A., Plotkin, D.J., Barbosa, J.A.Ruddle, F.H. Genetic transformation of mouse embryos by microinjection of purified DNA. Proc Natl Acad Sci U S A 77 (1980) 7380-7384.

[2] Wolfer, D.P., Crusio, W.E.Lipp, H.P. Knockout mice: simple solutions to the problems of genetic background and flanking genes. Trends Neurosci 25 (2002) $336-340$.

[3] Capecchi, M. An interview with...Mario Capecchi. Interview by Magdalena Skipper. Nat Rev Genet 6 (2005) 434.

[4] Capecchi, M.R. Gene targeting in mice: functional analysis of the mammalian genome for the twenty-first century. Nat Rev Genet 6 (2005) 507-512.

[5] Deng, C.X.Xu, X. Generation and analysis of Brcal conditional knockout mice. Methods Mol Biol 280 (2004) 185-200.

[6] Austin, C.P., Battey, J.F., Bradley, A., Bucan, M., Capecchi, M., Collins, F.S., Dove, W.F., Duyk, G., Dymecki, S., Eppig, J.T., Grieder, F.B., Heintz, N., Hicks, G., Insel, T.R., Joyner, A., Koller, B.H., Lloyd, K.C., Magnuson, T., Moore, M.W., Nagy, A., Pollock, J.D., Roses, A.D., Sands, A.T., Seed, B., Skarnes, W.C., Snoddy, J., Soriano, P., Stewart, D.J., Stewart, F., Stillman, B., Varmus, H., Varticovski, L., Verma, I.M., Vogt, T.F., von Melchner, H., Witkowski, J., Woychik, R.P., Wurst, W., Yancopoulos, G.D., Young, S.G.Zambrowicz, B. The knockout mouse project. Nat Genet 36 (2004) 921-924. 
[7] Calderon, A.J.Lavergne, J.A. RNA interference: a novel and physiologic mechanism of gene silencing with great therapeutic potential. P R Health Sci J 24 (2005) 27-33.

[8] Downward, J. RNA interference libraries prove their worth in hunt for tumor suppressor genes. Cell 121 (2005) 813-815.

[9] Fountaine, T.M., Wood, M.J.Wade-Martins, R. Delivering RNA interference to the mammalian brain. Curr Gene Ther 5 (2005) 399-410 .

[10] Wheeler, D.B., Carpenter, A.E.Sabatini, D.M. Cell microarrays and RNA interference chip away at gene function. Nat Genet 37 Suppl (2005) S25-30.

[11] Guo, S.Kemphues, K.J. par-1, a gene required for establishing polarity in C. elegans embryos, encodes a putative Ser/Thr kinase that is asymmetrically distributed. Cell 81 (1995) 611-620.

[12] Fire, A., Xu, S., Montgomery, M.K., Kostas, S.A., Driver, S.E.Mello, C.C. Potent and specific genetic interference by double-stranded RNA in Caenorhabditis elegans. Nature 391 (1998) 806-811.

[13] Prawitt, D., Brixel, L., Spangenberg, C., Eshkind, L., Heck, R., Oesch, F., Zabel, B.Bockamp, E. RNAi knock-down mice: an emerging technology for postgenomic functional genetics. Cytogenet Genome Res 105 (2004) 412-421.

[14] Bagasra, O.Prilliman, K.R. RNA interference: the molecular immune system. J Mol Histol 35 (2004) 545-553.

[15] Bernstein, E.Allis, C.D. RNA meets chromatin. Genes Dev 19 (2005) 1635-1655.

[16] Rao, M.Sockanathan, S. Molecular mechanisms of RNAi: implications for development and disease. Birth Defects Res C Embryo Today 75 (2005) 28-42. 
[17] Collins, R.E.Cheng, X. Structural domains in RNAi. FEBS Lett 579 (2005) 58415849 .

[18] Agrawal, N., Dasaradhi, P.V., Mohmmed, A., Malhotra, P., Bhatnagar, R.K.Mukherjee, S.K. RNA interference: biology, mechanism, and applications. Microbiol Mol Biol Rev 67 (2003) 657-685.

[19] Dalmay, T., Hamilton, A., Rudd, S., Angell, S.Baulcombe, D.C. An RNAdependent RNA polymerase gene in Arabidopsis is required for posttranscriptional gene silencing mediated by a transgene but not by a virus. Cell $101(2000) 543-553$.

[20] Lipardi, C., Wei, Q.Paterson, B.M. RNAi as random degradative PCR: siRNA primers convert mRNA into dsRNAs that are degraded to generate new siRNAs. Cell 107 (2001) 297-307.

[21] Stein, P., Svoboda, P., Anger, M.Schultz, R.M. RNAi: mammalian oocytes do it without RNA-dependent RNA polymerase. Rna 9 (2003) 187-192.

[22] Elbashir, S.M., Harborth, J., Lendeckel, W., Yalcin, A., Weber, K.Tuschl, T. Duplexes of 21-nucleotide RNAs mediate RNA interference in cultured mammalian cells. Nature 411 (2001) 494-498.

[23] Elbashir, S.M., Martinez, J., Patkaniowska, A., Lendeckel, W.Tuschl, T. Functional anatomy of siRNAs for mediating efficient RNAi in Drosophila melanogaster embryo lysate. Embo J 20 (2001) 6877-6888.

[24] Elbashir, S.M., Lendeckel, W.Tuschl, T. RNA interference is mediated by 21 - and 22-nucleotide RNAs. Genes Dev 15 (2001) 188-200. 
[25] Bridge, A.J., Pebernard, S., Ducraux, A., Nicoulaz, A.L.Iggo, R. Induction of an interferon response by RNAi vectors in mammalian cells. Nat Genet 34 (2003) 263-264.

[26] Jackson, A.L., Bartz, S.R., Schelter, J., Kobayashi, S.V., Burchard, J., Mao, M., Li, B., Cavet, G.Linsley, P.S. Expression profiling reveals off-target gene regulation by RNAi. Nat Biotechnol 21 (2003) 635-637.

[27] Sledz, C.A., Holko, M., de Veer, M.J., Silverman, R.H.Williams, B.R. Activation of the interferon system by short-interfering RNAs. Nat Cell Biol 5 (2003) 834839.

[28] Chi, J.T., Chang, H.Y., Wang, N.N., Chang, D.S., Dunphy, N.Brown, P.O. Genomewide view of gene silencing by small interfering RNAs. Proc Natl Acad Sci U S A 100 (2003) 6343-6346.

[29] Semizarov, D., Frost, L., Sarthy, A., Kroeger, P., Halbert, D.N.Fesik, S.W. Specificity of short interfering RNA determined through gene expression signatures. Proc Natl Acad Sci U S A 100 (2003) 6347-6352.

[30] van de Wetering, M., Oving, I., Muncan, V., Pon Fong, M.T., Brantjes, H., van Leenen, D., Holstege, F.C., Brummelkamp, T.R., Agami, R.Clevers, H. Specific inhibition of gene expression using a stably integrated, inducible smallinterfering-RNA vector. EMBO Rep 4 (2003) 609-615.

[31] Xia, X.G., Zhou, H., Ding, H., Affar el, B., Shi, Y.Xu, Z. An enhanced U6 promoter for synthesis of short hairpin RNA. Nucleic Acids Res 31 (2003) e100. 
[32] Coumoul, X., Li, W., Wang, R.H.Deng, C. Inducible suppression of Fgfr2 and Survivin in ES cells using a combination of the RNA interference (RNAi) and the Cre-LoxP system. Nucleic Acids Res 32 (2004) e85.

[33] Coumoul, X., Shukla, V., Li, C., Wang, R.H.Deng, C.X. Conditional knockdown of Fgfr2 in mice using Cre-LoxP induced RNA interference. Nucleic Acids Res 33 (2005) e102.

[34] Hohjoh, H. RNA interference (RNA(i)) induction with various types of synthetic oligonucleotide duplexes in cultured human cells. FEBS Lett 521 (2002) 195-199.

[35] Hohjoh, H. Enhancement of RNAi activity by improved siRNA duplexes. FEBS Lett 557 (2004) 193-198.

[36] Yu, J.Y., DeRuiter, S.L.Turner, D.L. RNA interference by expression of shortinterfering RNAs and hairpin RNAs in mammalian cells. Proc Natl Acad Sci U S A 99 (2002) 6047-6052.

[37] Kamath, R.S.Ahringer, J. Genome-wide RNAi screening in Caenorhabditis elegans. Methods 30 (2003) 313-321.

[38] Kamath, R.S., Fraser, A.G., Dong, Y., Poulin, G., Durbin, R., Gotta, M., Kanapin, A., Le Bot, N., Moreno, S., Sohrmann, M., Welchman, D.P., Zipperlen, P.Ahringer, J. Systematic functional analysis of the Caenorhabditis elegans genome using RNAi. Nature 421 (2003) 231-237.

[39] Wianny, F.Zernicka-Goetz, M. Specific interference with gene function by double-stranded RNA in early mouse development. Nat Cell Biol 2 (2000) 70-75. 
[40] Kunath, T., Gish, G., Lickert, H., Jones, N., Pawson, T.Rossant, J. Transgenic RNA interference in ES cell-derived embryos recapitulates a genetic null phenotype. Nat Biotechnol 21 (2003) 559-561.

[41] Lickert, H., Cox, B., Wehrle, C., Taketo, M.M., Kemler, R.Rossant, J. Dissecting Wnt/beta-catenin signaling during gastrulation using RNA interference in mouse embryos. Development 132 (2005) 2599-2609.

[42] Rubinson, D.A., Dillon, C.P., Kwiatkowski, A.V., Sievers, C., Yang, L., Kopinja, J., Rooney, D.L., Ihrig, M.M., McManus, M.T., Gertler, F.B., Scott, M.L.Van Parijs, L. A lentivirus-based system to functionally silence genes in primary mammalian cells, stem cells and transgenic mice by RNA interference. Nat Genet 33 (2003) 401-406.

[43] Tiscornia, G., Singer, O., Ikawa, M.Verma, I.M. A general method for gene knockdown in mice by using lentiviral vectors expressing small interfering RNA. Proc Natl Acad Sci U S A 100 (2003) 1844-1848.

[44] Hemann, M.T., Fridman, J.S., Zilfou, J.T., Hernando, E., Paddison, P.J., CordonCardo, C., Hannon, G.J.Lowe, S.W. An epi-allelic series of p53 hypomorphs created by stable RNAi produces distinct tumor phenotypes in vivo. Nat Genet 33 (2003) 396-400.

[45] Liu, F., Song, Y.Liu, D. Hydrodynamics-based transfection in animals by systemic administration of plasmid DNA. Gene Ther 6 (1999) 1258-1266.

[46] Wolff, J.A.Budker, V. The mechanism of naked DNA uptake and expression. Adv Genet 54 (2005) 3-20. 
[47] Zhang, G., Budker, V.Wolff, J.A. High levels of foreign gene expression in hepatocytes after tail vein injections of naked plasmid DNA. Hum Gene Ther 10 (1999) 1735-1737.

[48] Lewis, D.L., Hagstrom, J.E., Loomis, A.G., Wolff, J.A.Herweijer, H. Efficient delivery of siRNA for inhibition of gene expression in postnatal mice. Nat Genet 32 (2002) 107-108.

[49] McCaffrey, A.P.Kay, M.A. A story of mice and men. Gene Ther 9 (2002) 1563.

[50] McCaffrey, A.P., Meuse, L., Pham, T.T., Conklin, D.S., Hannon, G.J.Kay, M.A. RNA interference in adult mice. Nature 418 (2002) 38-39.

[51] McCaffrey, A.P., Nakai, H., Pandey, K., Huang, Z., Salazar, F.H., Xu, H., Wieland, S.F., Marion, P.L.Kay, M.A. Inhibition of hepatitis B virus in mice by RNA interference. Nat Biotechnol 21 (2003) 639-644.

[52] Song, E., Lee, S.K., Wang, J., Ince, N., Ouyang, N., Min, J., Chen, J., Shankar, P.Lieberman, J. RNA interference targeting Fas protects mice from fulminant hepatitis. Nat Med 9 (2003) 347-351.

[53] Sorensen, D.R., Leirdal, M.Sioud, M. Gene silencing by systemic delivery of synthetic siRNAs in adult mice. J Mol Biol 327 (2003) 761-766.

[54] Hasuwa, H., Kaseda, K., Einarsdottir, T.Okabe, M. Small interfering RNA and gene silencing in transgenic mice and rats. FEBS Lett 532 (2002) 227-230.

[55] Wiznerowicz, M.Trono, D. Conditional suppression of cellular genes: lentivirus vector-mediated drug-inducible RNA interference. J Virol 77 (2003) 8957-8961.

[56] Sarkar, S.N.Das, H.K. Regulatory roles of presenilin-1 and nicastrin in neuronal differentiation during in vitro neurogenesis. J Neurochem 87 (2003) 333-343. 
[57] Miyagishi, M.Taira, K. Development and application of siRNA expression vector. Nucleic Acids Res Suppl (2002) 113-114.

[58] Miyagishi, M.Taira, K. U6 promoter-driven siRNAs with four uridine 3' overhangs efficiently suppress targeted gene expression in mammalian cells. Nat Biotechnol 20 (2002) 497-500.

[59] Matsukura, S., Jones, P.A.Takai, D. Establishment of conditional vectors for hairpin siRNA knockdowns. Nucleic Acids Res 31 (2003) e77.

[60] Chang, H.S., Lin, C.H., Chen, Y.C.Yu, W.C. Using siRNA technique to generate transgenic animals with spatiotemporal and conditional gene knockdown. Am J Pathol 165 (2004) 1535-1541.

[61] Ventura, A., Meissner, A., Dillon, C.P., McManus, M., Sharp, P.A., Van Parijs, L., Jaenisch, R.Jacks, T. Cre-lox-regulated conditional RNA interference from transgenes. Proc Natl Acad Sci U S A 101 (2004) 10380-10385.

[62] Coumoul, X.Deng, C.X. Roles of FGF receptors in mammalian development and congenital diseases. Birth Defects Res C Embryo Today 69 (2003) 286-304.

[63] Lakso, M., Pichel, J.G., Gorman, J.R., Sauer, B., Okamoto, Y., Lee, E., Alt, F.W.Westphal, H. Efficient in vivo manipulation of mouse genomic sequences at the zygote stage. Proc Natl Acad Sci U S A 93 (1996) 5860-5865.

[64] Xu, X., Weinstein, M., Li, C., Naski, M., Cohen, R.I., Ornitz, D.M., Leder, P.Deng, C. Fibroblast growth factor receptor 2 (FGFR2)-mediated reciprocal regulation loop between FGF8 and FGF10 is essential for limb induction. Development 125 (1998) 753-765. 
[65] Li, C., Guo, H., Xu, X., Weinberg, W.Deng, C.X. Fibroblast growth factor receptor 2 (Fgfr2) plays an important role in eyelid and skin formation and patterning. Dev Dyn 222 (2001) 471-483.

[66] Li, X., Chen, Y., Scheele, S., Arman, E., Haffner-Krausz, R., Ekblom, P.Lonai, P. Fibroblast growth factor signaling and basement membrane assembly are connected during epithelial morphogenesis of the embryoid body. J Cell Biol 153 (2001) 811-822.

[67] Nelson, D.K.Williams, T. Frontonasal process-specific disruption of AP-2alpha results in postnatal midfacial hypoplasia, vascular anomalies, and nasal cavity defects. Dev Biol 267 (2004) 72-92.

[68] Weinstein, M., Xu, X., Ohyama, K.Deng, C.X. FGFR-3 and FGFR-4 function cooperatively to direct alveogenesis in the murine lung. Development 125 (1998) 3615-3623.

[69] Gaudet, F., Hodgson, J.G., Eden, A., Jackson-Grusby, L., Dausman, J., Gray, J.W., Leonhardt, H.Jaenisch, R. Induction of tumors in mice by genomic hypomethylation. Science 300 (2003) 489-492.

[70] Kioussis, D.Festenstein, R. Locus control regions: overcoming heterochromatininduced gene inactivation in mammals. Curr Opin Genet Dev 7 (1997) 614-619.

[71] Frazar, T.F., Weisbein, J.L., Anderson, S.M., Cline, A.P., Garrett, L.J., Felsenfeld, G., Gallagher, P.G.Bodine, D.M. Variegated expression from the murine band $3(\mathrm{AE} 1)$ promoter in transgenic mice is associated with mRNA transcript initiation at upstream start sites and can be suppressed by the addition 
of the chicken beta-globin 5' HS4 insulator element. Mol Cell Biol 23 (2003) 4753-4763.

[72] Soriano, P. Generalized lacZ expression with the ROSA2 6 Cre reporter strain. Nat Genet 21 (1999) 70-71.

[73] Gilmore, I.R., Fox, S.P., Hollins, A.J., Sohail, M.Akhtar, S. The design and exogenous delivery of siRNA for post-transcriptional gene silencing. J Drug Target 12 (2004) 315-340.

[74] Sandy, P., Ventura, A.Jacks, T. Mammalian RNAi: a practical guide. Biotechniques 39 (2005) 215-224.

[75] Dickins, R.A., Hemann, M.T., Zilfou, J.T., Simpson, D.R., Ibarra, I., Hannon, G.J.Lowe, S.W. Probing tumor phenotypes using stable and regulated synthetic microRNA precursors. Nat Genet 37 (2005) 1289-1295.

[76] Silva, J.M., Li, M.Z., Chang, K., Ge, W., Golding, M.C., Rickles, R.J., Siolas, D., Hu, G., Paddison, P.J., Schlabach, M.R., Sheth, N., Bradshaw, J., Burchard, J., Kulkarni, A., Cavet, G., Sachidanandam, R., McCombie, W.R., Cleary, M.A., Elledge, S.J.Hannon, G.J. Second-generation shRNA libraries covering the mou se and human genomes. Nat Genet 37 (2005) 1281-1288.

[77] Chen, L., Li, D., Li, C., Engel, A.Deng, C.X. A Ser250Trp substitution in mouse fibroblast growth factor receptor 2 (Fgfr2) results in craniosynostosis. Bone 33 (2003) 169-178. 
Fig. 1 


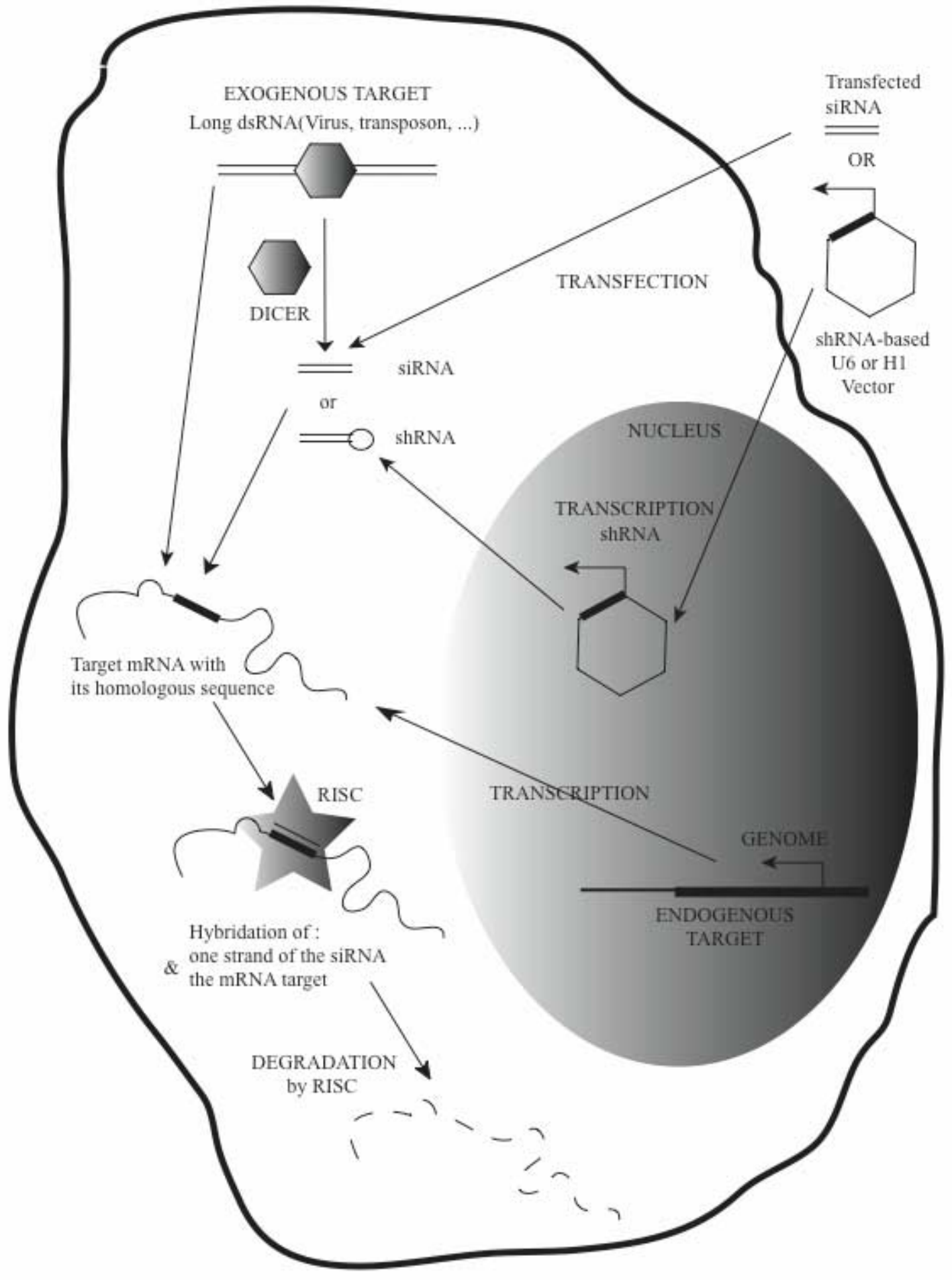

Fig. 2 
A U6-ploxPneo-Fgfr2
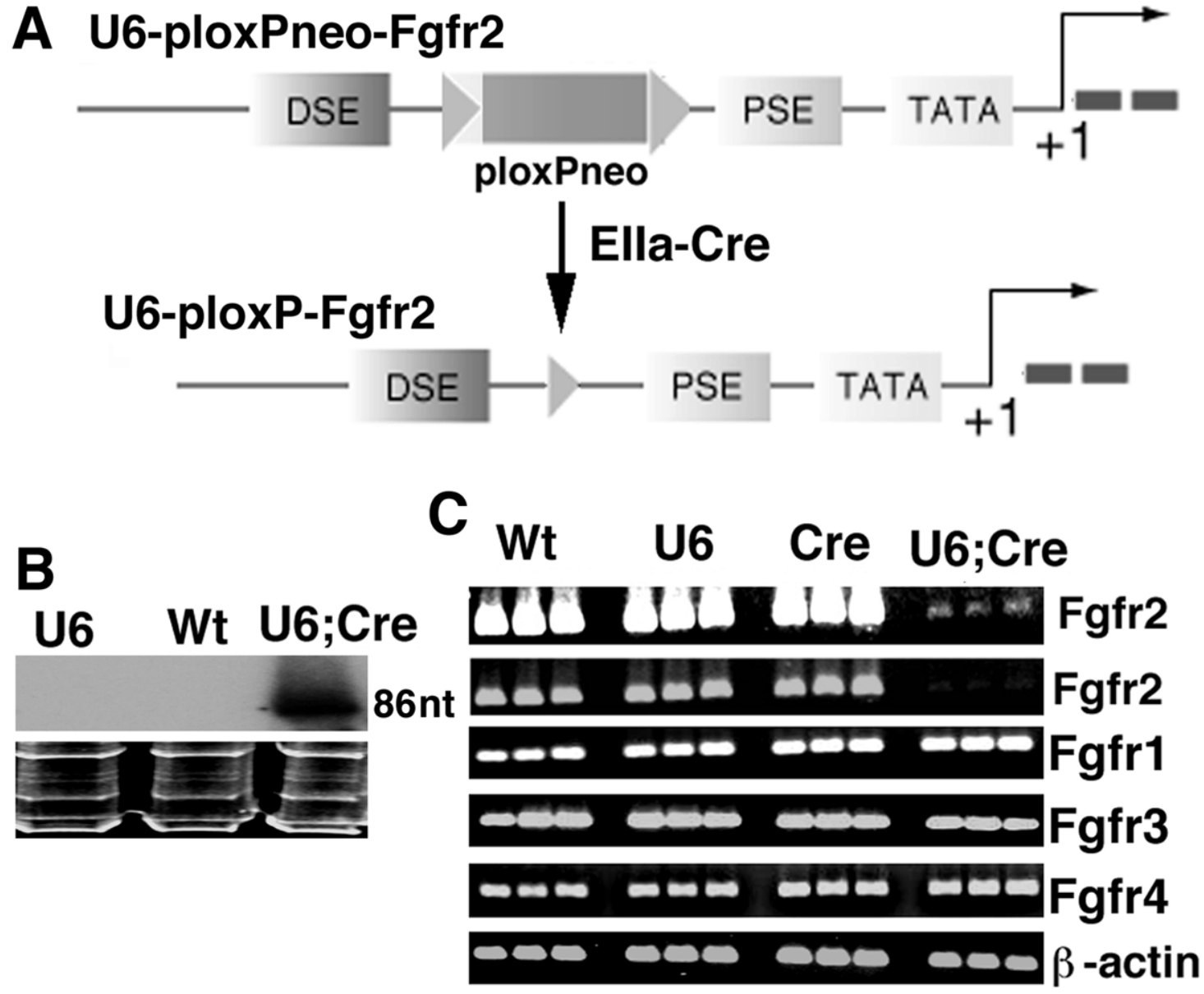

Fig. 3 


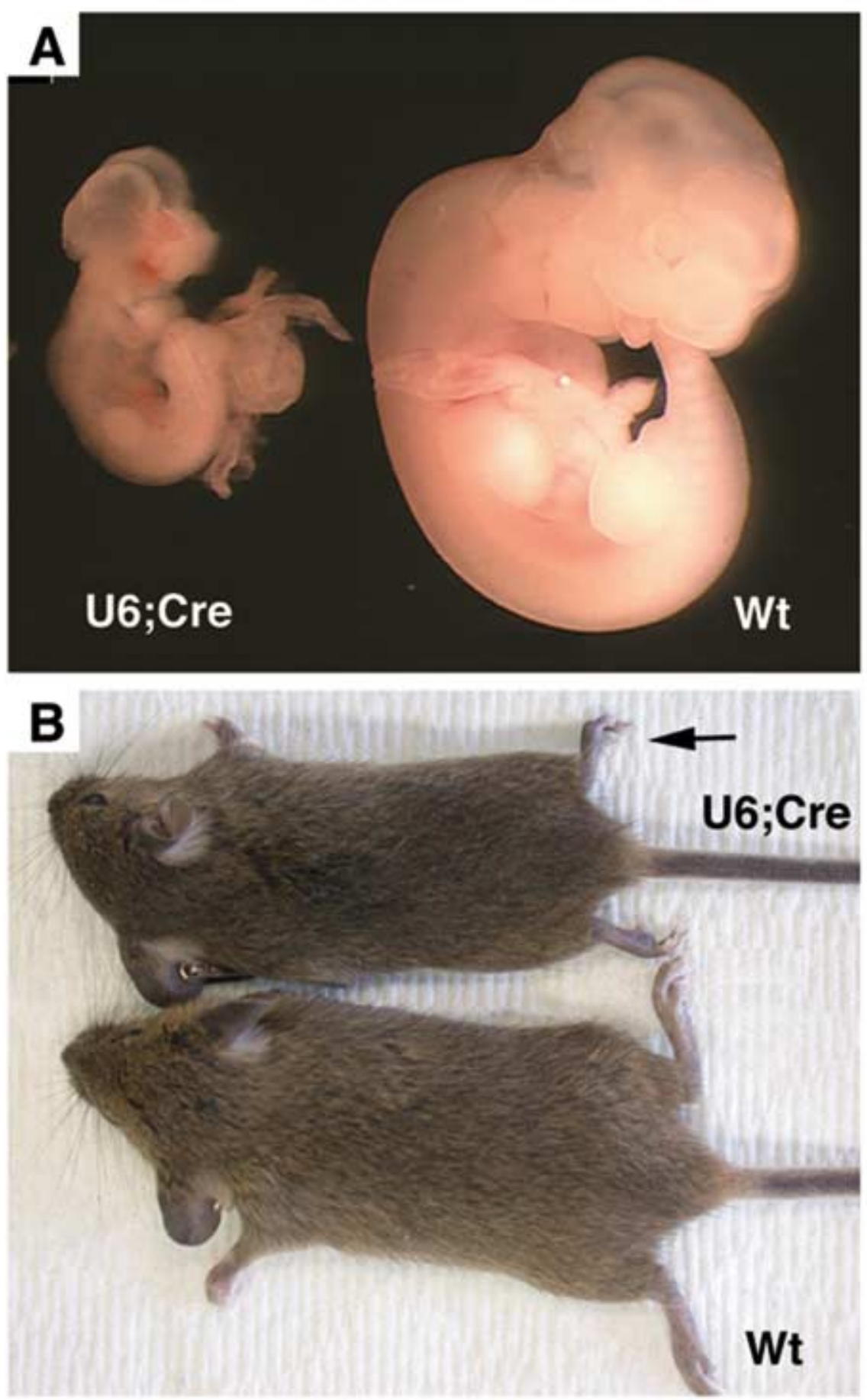




\section{Figure 1
Click here to download high resolution image}

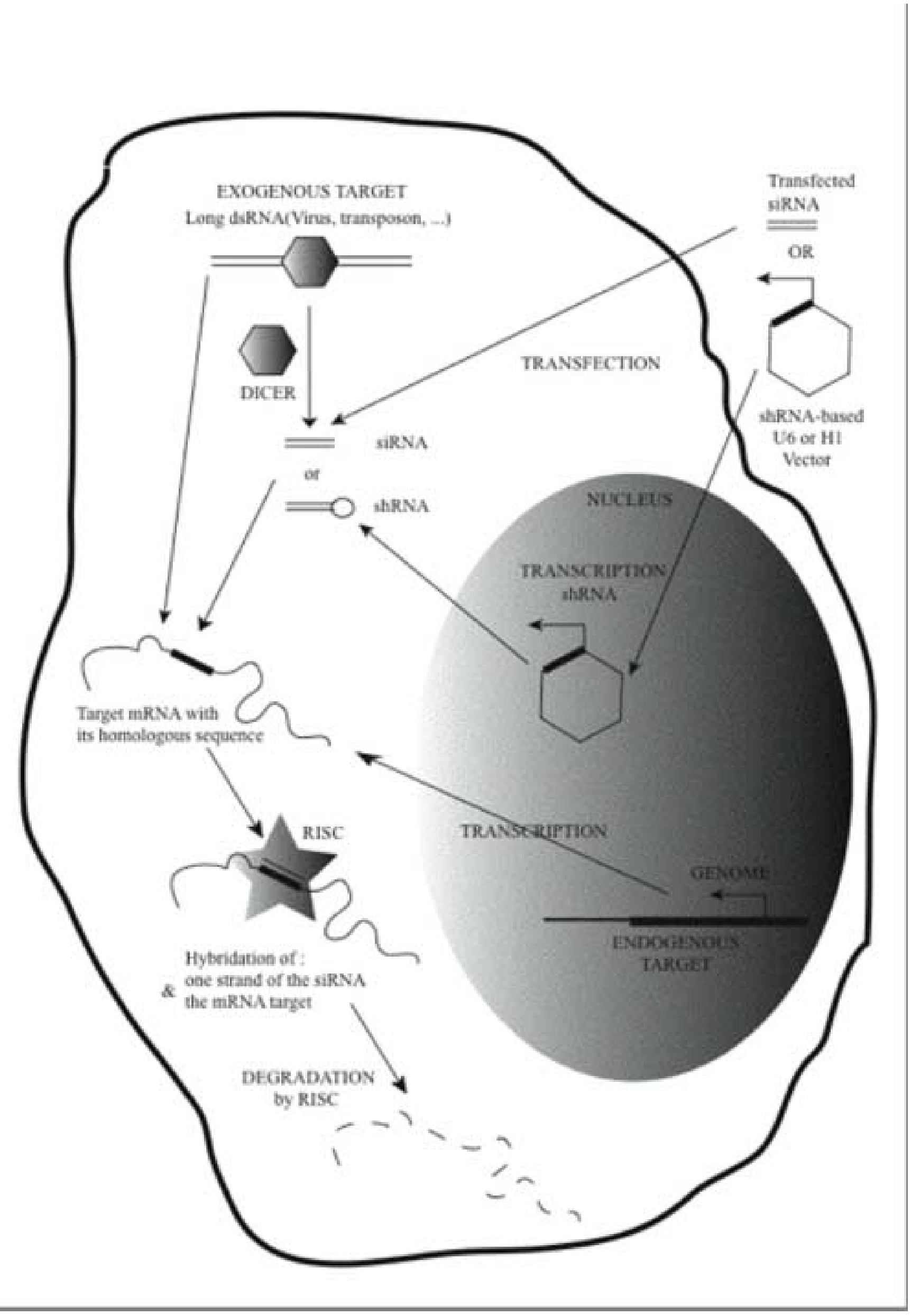

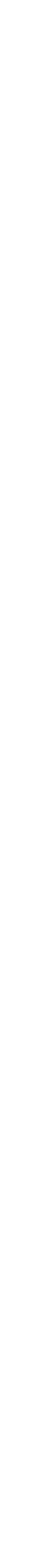


Figure 2

Click here to download high resolution image

A U6-ploxPneo-Fgfr2
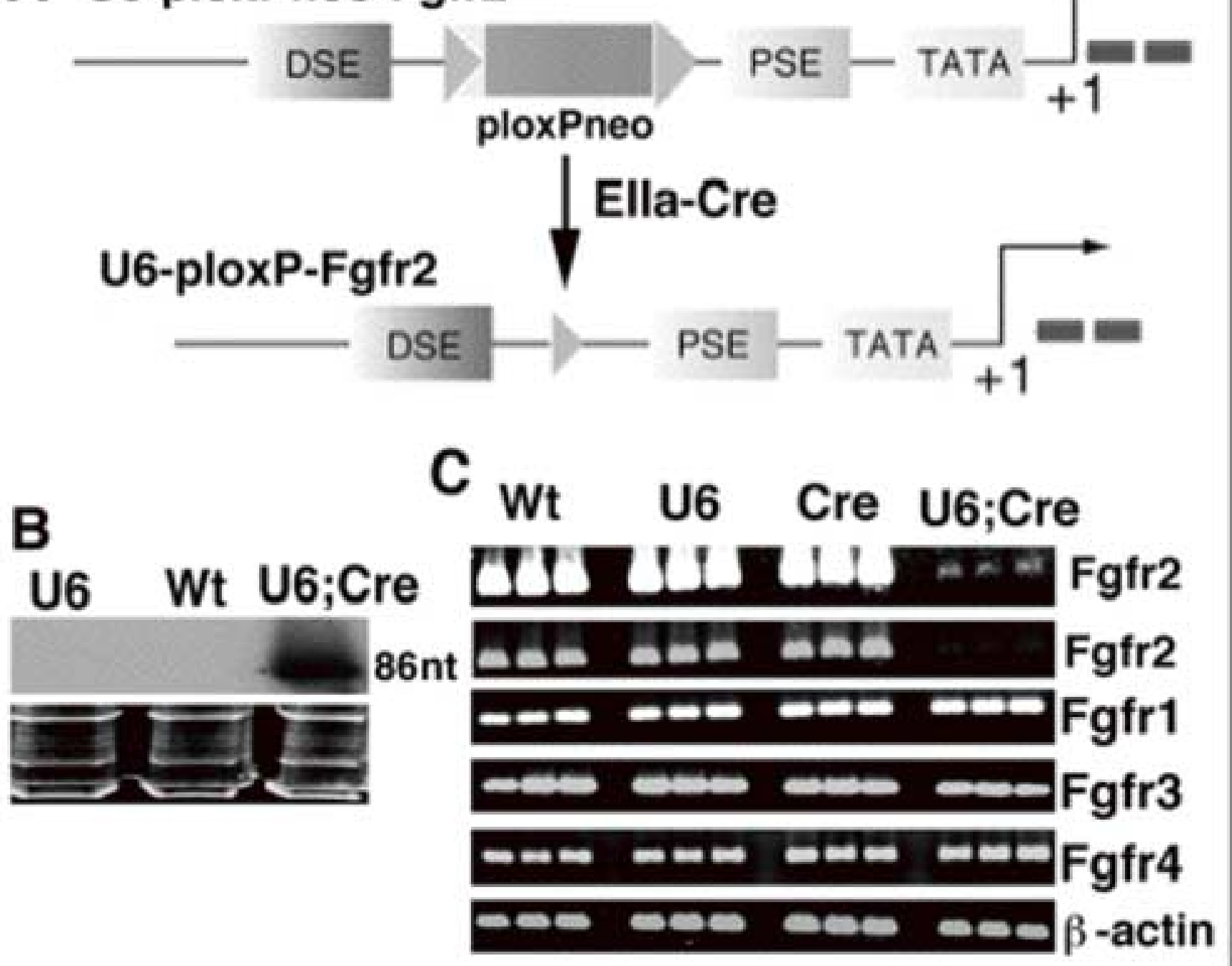
Figure 3
Click here to download high resolution image
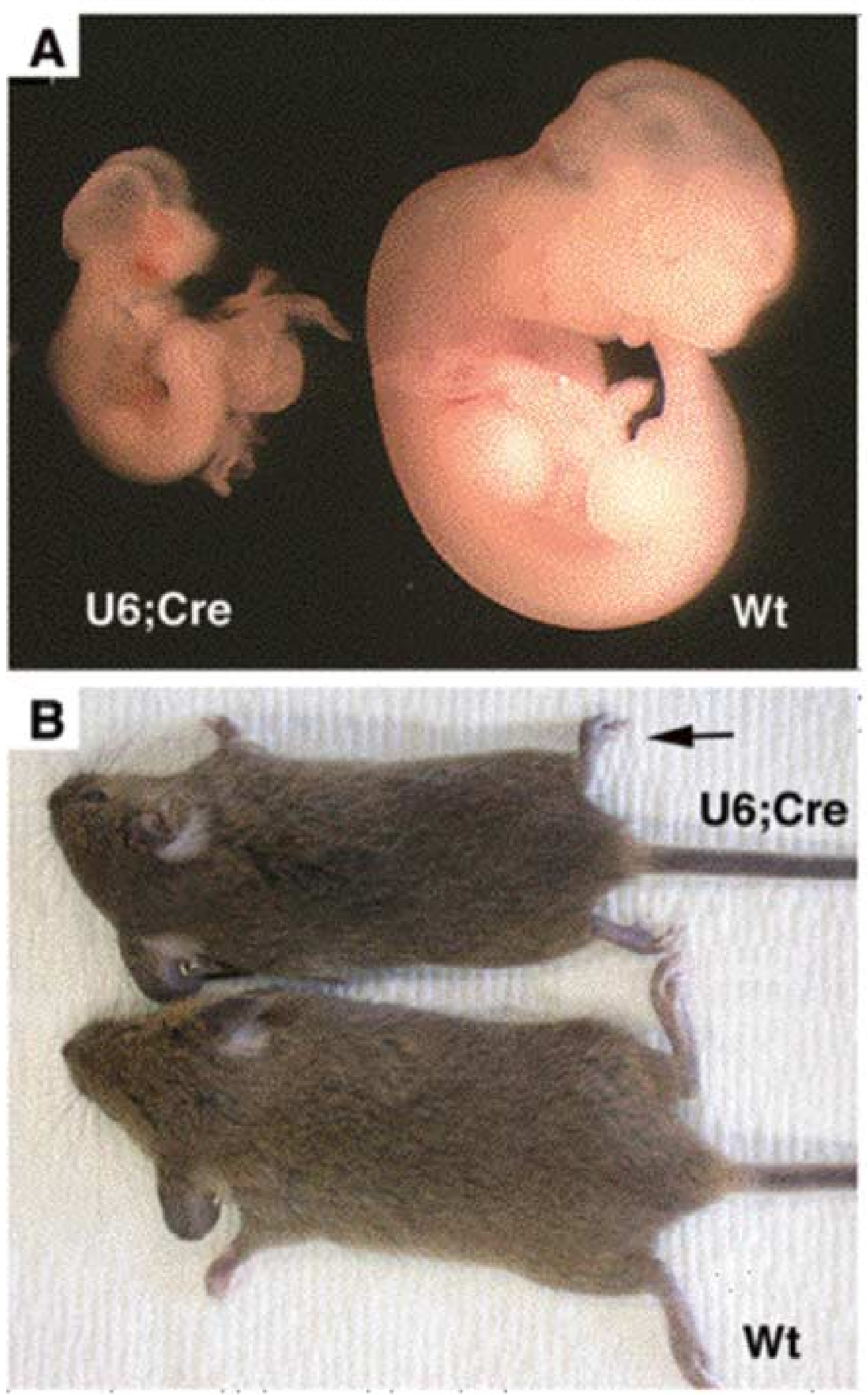

\section{U6;Cre}

\section{U6;Cre}

